\title{
Lymphocyte Transformation in Malnourished Children
}

\author{
ERICA SELLMEYER, * E. BHETTAY, A. S. TRUSWELL, $\dagger$ O. L. MEYERS, and \\ J. D. L. HANSEN $\ddagger$ \\ From the Departments of Medicine, Paediatrics, and Child Health, University of Cape Town Medical School, Observatory, \\ Cape Town, South Africa
}

\begin{abstract}
Sellmeyer, E., Bhettay, E., Truswell, A. S., Meyers, O. L., and Hansen, J. D. L. (1972). Archives of Disease in Childhood, 47, 429. Lymphocyte transformation in malnourished children. In vitro lymphocyte stimulation with phytohaemagglutinin gave subnormal transformation values in children with proteincalorie malnutrition. It is suggested that impaired cell-mediated immunity may be one important mechanism for the susceptibility of malnourished children to infections. Lymphocyte transformation was also subnormal in children with measles and gastroenteritis but tended to be increased in pneumonia.
\end{abstract}

That infection often contributes to lowering of nutritional status is easier to prove than that a state of poor nutrition results in diminished resistance to infection (Scrimshaw, Taylor, and Gordon, 1968; Lowenstein, 1970). Several studies confirm the long-held clinical impression that infectious diseases adversely affect nutritional status (Venkatachalam and Patwardhan, 1953; Truswell et al., 1959; Wilson, Bressani, and Scrimshaw, 1961).

Infection and protein-calorie malnutrition (PCM) frequently coexist; the consequences are usually more serious than if either were present alone (Vitale, 1971). A latent protein deficiency state may be aggravated by any infection (Williams, 1953; Trowell, Davies, and Dean, 1954), particularly pneumonia, measles (Hendrickse, 1967; Morley, 1969), gastroenteritis (Gopalan and Ramalingaswami, 1955), and tuberculosis.

Kwashiorkor predisposes to complicating infections (Trowell et al., 1954; Brown and Katz, 1965; Phillips and Wharton, 1968), but the mechanism of this effect remains unclear (Gopalan and Ramalingaswami, 1955). Serum immunoglobulin concentrations and isohaemagglutinins have been found normal to high in malnourished children (Kahn, Stein, and Zoutendyk, 1957; Keet and Thom, 1969; McFarlane et al., 1970; Watson and Freesemann, 1970), and synthesis of gamma-

Received 15 November 1971.

*Department of Botany, University of Natal, Pietermaritzburg, South Africa.

tDepartment of Nutrition, Queen Elizabeth College, Campden Hill, London W8 7AH.

$\ddagger$ Department of Pediatrics, Witwatersrand University, Transvaal Memorial Hospital, Johannesburg, South Africa. globulin, unlike albumin, is not impaired in kwashiorkor (Cohen and Hansen, 1962).

The frequent finding of thymic atrophy (Watts, 1969), low BCG conversion rates (Hutt, 1969), and impaired tuberculin skin responses (Harland and Brown, 1965; Lloyd, 1968) in malnourished children led us to study the status of cell-mediated immune responses in such patients.

Lymphocyte stimulation in cultures from peripheral blood has been described as an in vitro reflection of immunological reactivity and has been associated with delayed hypersensitivity (Ling, 1968; Gatti and Good, 1970). We report here our first results of a study of phytohaemagglutinin (PHA)-induced lymphocyte transformation in children with PCM, and some commonly associated infectious diseases.

\section{Patients and Methods}

Fifty-six blood samples were collected from children at the Red Cross Children's Hospital, the Somerset Hospital, and City Hospital, Cape Town, and Livingstone Hospital, Port Elizabeth. The patients were suffering from PCM (kwashiorkor or marasmus), measles, pneumonia, gastroenteritis, and miscellaneous conditions.

Ten children served as healthy controls. They had recovered from various diseases or were healthy sibs of children in hospital (for details of patients and controls see Tables I-VI). The weights in the Tables are expressed as a percentage of the 50th centile weightfor-age in normal Boston children (Vaughan, 1969).

Heparinized venous blood, 10 to $12 \mathrm{ml}$, was required for lymphocyte culture. In preparing the lymphocytes for culture the method of Eijsvoogel and Schellekens 
TABLE I

Normals

\begin{tabular}{|c|c|c|c|c|}
\hline Case No. & Age $(y r)$ & Expected Weight (\%) & Lymphocyte Response & Comments \\
\hline $\begin{array}{l}\text { N1 } \\
\text { N2 } \\
\text { N4 } \\
\text { N5 } \\
\text { N6 } \\
\text { N7 } \\
\text { N8 } \\
\text { N9 } \\
\text { N10 }\end{array}$ & $\begin{array}{c}6 / 12 \\
10 / 12 \\
11 / 12 \\
3 / 12 \\
3 / 12 \\
4 \\
5 \\
8 \\
9 \\
10\end{array}$ & $\begin{array}{r}80 \\
90 \\
86 \\
103 \\
100 \\
85 \\
83 \\
86 \\
82 \\
103\end{array}$ & $\begin{array}{l}204 \\
124 \\
288 \\
162 \\
178 \\
215 \\
201 \\
281 \\
327 \\
221\end{array}$ & $\begin{array}{l}\text { Recovered gastroenteritis (G9) } \\
\text { Recovered gastroenteritis (G12) } \\
\text { Recovered gastroenteritis (G8) } \\
\text { Recovered pneumonia } \\
\text { Recovered pneumonia } \\
\text { Healthy sib } \\
\text { Treated hypothyroidism } \\
\text { Healthy sib } \\
\text { Recovered rheumatic fever } \\
\text { Recovered meningitis }\end{array}$ \\
\hline
\end{tabular}

Mean $(\mathrm{cpm})=220$

Note: Arranged in order of increasing age.

(1965) and Schellekens and Eijsvoogel (1968) was followed with a few minor modifications. The lymphocytes were counted in duplicate in a haemocytometer (any red cells being lysed with $2 \%$ acetic acid).

Lymphocytes were cultured in Eagle's Minimum Essential Medium for suspension cultures, with Lglutamine (Grand Island Biological Co., New York) plus $20 \%$ sterile fetal calf serum, penicillin (100 U per $\mathrm{ml})$, and streptomycin $(100 \mu \mathrm{g} / \mathrm{ml})$ to a final concentration of $1 \times 10^{6}$ lymphocytes per $\mathrm{ml}$. $3 \mathrm{ml}$ of suspension ( $3 \times 10^{6}$ lymphocytes) were cultured in screwcapped test tubes at $37^{\circ} \mathrm{C}$ for 48 hours.

For stimulation, $0.05 \mathrm{ml}$ PHA (Burroughs Wellcome) was added to at least 3 tubes, with $0.05 \mathrm{ml} 0.9 \%$ saline as control in another 3 tubes. The $p \mathrm{H}$ was checked daily and corrected if necessary with $20 \% \mathrm{CO}_{2}$ in air or with $0 \cdot 1 \mathrm{~N}-\mathrm{HCl}$. DNA synthesis was measured by adding, 24 hours before harvesting, $0.2 \mu \mathrm{Ci}$ tritiated thymidine with carrier thymidine added to each tube to a final concentration of $2.9 \mu \mathrm{g} / \mathrm{ml}$.

At harvesting the cells were removed from the incubator, centrifuged, washed twice in ice-cold saline, then in ice-cold $2 \%$ acetic acid. The sediment was left to dry at $37^{\circ} \mathrm{C}$. $0.5 \mathrm{ml}$ hydroxide of hyamine $10 \mathrm{x}$
(Packard) was added to resuspend the sediment. The suspension was left overnight in a dark cupboard. $0.5 \mathrm{ml}$ absolute ethanol was then added, the tubes were shaken and kept in a $45^{\circ} \mathrm{C}$ waterbath for 3 hours. $10 \mathrm{ml}$ scintillating liquid (Popop $0.3 \mathrm{~g}$ and Ppo $3 \mathrm{~g}$ per litre of toluene) were added and radioactivity counted in a Beckman liquid scintillation counter.

Results (Levene, 1970; Folb and Trounce, 1971) were expressed as (cpm $=$ counts per minute):

$$
\begin{gathered}
\frac{\text { PHA cells cpm-background cpm }}{\text { Unstimulated cells cpm-background cpm }} \\
\text { Results }
\end{gathered}
$$

\section{Results}

The results are summarized in Tables I to IV.

Normal controls (Table I). There were 10 patients in this group whose weights were $80 \%$ or more than the expected weight for age. All were healthy at the time of study. The first 3 patients also appear in Table IV, but had completely recovered when blood samples were collected 4 to 7 weeks after the episode of gastroenteritis. As shown in Table $I$, though the values obtained

TABLE II

\begin{tabular}{|c|c|c|c|c|c|}
\hline $\begin{array}{l}\text { Case } \\
\text { No. }\end{array}$ & $\begin{array}{l}\text { Age } \\
(y r)\end{array}$ & $\begin{array}{c}\text { Expected } \\
\text { Weight (\%) }\end{array}$ & $\begin{array}{l}\text { Serum } \\
\text { Albumin }\end{array}$ & $\begin{array}{l}\text { Lymphocyte } \\
\text { Response }\end{array}$ & Comments \\
\hline $\begin{array}{l}\text { K1 } \\
\text { K2 } \\
\text { K3 } \\
\text { K4 } \\
\text { K5 } \\
\text { K6 } \\
\text { K7 } \\
\text { K8 } \\
\text { K9 } \\
\text { K10 } \\
\text { K11 }\end{array}$ & $\begin{array}{l}1 \frac{1}{2} \\
4 \\
5 \frac{8}{4} \\
1 \frac{1}{2} \\
1 \frac{8}{4} \\
6 \\
2 \frac{1}{2} \\
2 \\
1 \frac{1}{2} \\
1 \frac{1}{4} \\
1 \frac{1}{4}\end{array}$ & $\begin{array}{r}56 \\
63 \\
61 \\
42 \\
94 \\
69 \\
62 \\
110 \\
76 \\
63 \\
75\end{array}$ & $\begin{array}{l}2 \cdot 7 \\
1 \cdot 7 \\
1 \cdot 5 \\
2 \cdot 2 \\
2 \cdot 0 \\
1 \cdot 7 \\
1 \cdot 4 \\
1 \cdot 5 \\
2 \cdot 2 \\
4 \cdot 5 \\
1 \cdot 9\end{array}$ & $\begin{array}{r}7 \\
18 \\
18 \\
27 \\
34 \\
45 \\
45 \\
49 \\
60 \\
71 \\
137\end{array}$ & $\begin{array}{l}\text { Severe kwashiorkor and gastroenteritis; on IV drip } \\
\text { Kwashiorkor } \\
\text { Craniosynostosis and kwashiorkor } \\
\text { Kwashiorkor } \\
\text { Kwashiorkor } \\
\text { Kwashiorkor } \\
\text { Kwashiorkor; on IV drip night before } \\
\text { Kwashiorkor } \\
\text { Kwashiorkor } \\
\text { Marasmus } \\
\text { Kwashiorkor; } 6 \text { days after admission }\end{array}$ \\
\hline
\end{tabular}

Protein-calorie Malnutrition 
TABLE III

Measles

\begin{tabular}{|c|c|c|c|c|c|}
\hline $\begin{array}{l}\text { Case } \\
\text { No. }\end{array}$ & $\begin{array}{l}\text { Age } \\
(\mathrm{yr})\end{array}$ & $\begin{array}{c}\text { Expected } \\
\text { Weight }(\%)\end{array}$ & $\begin{array}{l}\text { Stage of } \\
\text { Disease }\end{array}$ & $\begin{array}{c}\text { Lymphocyte } \\
\text { Response }\end{array}$ & Comments \\
\hline $\begin{array}{l}\text { M1 } \\
\text { M3 } \\
\text { M4 } \\
\text { M5 } \\
\text { M6 } \\
\text { M7 }\end{array}$ & $\begin{array}{r}\frac{9}{4} \\
2 \frac{1}{1} \\
1 \frac{1}{8} \\
1 \frac{8}{8} \\
\frac{2}{4} \\
2 \frac{1}{2} \\
\frac{1}{2}\end{array}$ & $\begin{array}{l}89 \\
66 \\
70 \\
76 \\
80 \\
79 \\
80\end{array}$ & $\begin{array}{l}\text { Acute } \\
\text { Acute } \\
3 \text { wk } \\
3 \text { wk } \\
4 \text { wk } \\
4-5 \text { wk } \\
5 \text { wk }\end{array}$ & $\begin{array}{r}3 \\
3 \\
29 \\
64 \\
19 \\
19 \\
9\end{array}$ & $\begin{array}{l}\text { Diarrhoea } \\
\text { Diarrhoea } \\
\text { Diarrhoea } \\
1 \text { month after kwashiorkor; } 3 \text { weeks after pneumonia } \\
\text { Diarrhoea } \\
\text { Diarrhoea }\end{array}$ \\
\hline
\end{tabular}

Mean $(\mathrm{cpm})=20.9$

Unstimulated $=23.9$

Stimulated $=1497 \cdot 3$

Note: Arranged in order of increasing time from onset of measles.

extend over a fairly wide range, only 3 patients have readings less than 200 . The highest value was found in a patient who had previously been admitted with rheumatic fever but was asymptomatic when studied. The patient with hypothyroidism was being treated with thyroxine and was thriving clinically as well as anthropometrically.

Protein-calorie malnutrition (Table II). All 11 patients were suffering from dietary malnutrition. All had oedema, hypoalbuminaemia, growth retardation, and other features of kwashiorkor, except K10 who had marasmus. One patient had craniosynostosis. Patients who had pneumonia with incidental malnutrition appear in Table V. Compared with the controls there was a significant depression of lymphocyte response to PHA stimulation ( $P<0.001$ by Mann-Whitney $U$ test). All had blood samples taken within a day or two of being admitted to the wards except for K11 whose blood was taken on the 6th day and who had the highest lymphocyte response.
Whether a similar value would have been obtained earlier or whether recovery could possibly be so rapid cannot at present be stated with confidence.

Measles (Table III). The responses in the measles group were uniformly low and significantly less than in the controls $(P<0.001)$. It is noteworthy that the most marked depression occurred in patients during the acute phase when the rash was coming out. The least degree of depression occurred in a patient who had a complicating pneumonia.

Gastroenteritis (Table IV). All 12 patients in this group had responses less than normal ( $P<0.001)$. This depression seemed to be independent of nutritional status, and since some patients were dehydrated while others had just been rehydrated, the state of hydration did not appear to be a major contributory factor. However, Cases G8, G9, and G12 in Table IV were retested after full recovery and at follow-up clinic a month

TABLE IV

Gastroenteritis (Excluding Measles)

\begin{tabular}{|c|c|c|c|c|}
\hline $\begin{array}{l}\text { Case } \\
\text { No. }\end{array}$ & $\begin{array}{l}\text { Age } \\
(y r)\end{array}$ & $\begin{array}{c}\text { Expected } \\
\text { Weight (\%) }\end{array}$ & $\begin{array}{c}\text { Lymphocyte } \\
\text { Response }\end{array}$ & Comments \\
\hline $\begin{array}{l}\text { G1 } \\
\text { G2 } \\
\text { G3 } \\
\text { G4 } \\
\text { G5 } \\
\text { G6 } \\
\text { G7 } \\
\text { G8 } \\
\text { G9 } \\
\text { G10 } \\
\text { G11 } \\
\text { G12 }\end{array}$ & $\begin{array}{rr}1 & 3 / 12 \\
& \\
& 8 / 12 \\
1 & 6 / 12 \\
5 / 12 \\
4 / 12 \\
4 \quad \\
1 & 9 / 12 \\
2 & 3 / 12 \\
10 / 12 \\
5 / 12 \\
25 / 12 \\
4 / 12 \\
9 / 12\end{array}$ & $\begin{array}{l}40 \\
\\
48 \\
49 \\
70 \\
72 \\
72 \\
76 \\
78 \\
80 \\
81 \\
91 \\
98\end{array}$ & $\begin{array}{r}38 \\
\\
68 \\
22 \\
32 \\
99 \\
43 \\
58 \\
68 \\
7 \\
15 \\
12 \\
10\end{array}$ & $\begin{array}{l}\text { Chronic gastroenteritis; grossly underweight; } \\
\text { dehydrated; had pneumonia } \\
\text { IV drip just completed } \\
\text { Dehydrated } \\
\text { Chronic gastroenteritis; dehydrated } \\
\text { Dehydrated; on IV fluids } \\
\text { On IV fluids } \\
\text { IV drip just completed } \\
\text { IV drip just completed } \\
\text { Dehydrated; on IV fluids } \\
\text { IV drip just completed } \\
\text { IV drip just completed } \\
\text { IV drip just completed }\end{array}$ \\
\hline
\end{tabular}

Note: Arranged in ascending order of percentage expected weight. 
TABLE V

Pneumonia

\begin{tabular}{|c|c|c|c|c|}
\hline $\begin{array}{l}\text { Case } \\
\text { No. }\end{array}$ & $\begin{array}{l}\text { Age } \\
(y r)\end{array}$ & $\begin{array}{c}\text { Expected } \\
\text { Weight (\%) }\end{array}$ & $\begin{array}{c}\text { Lymphocyte } \\
\text { Response }\end{array}$ & Comments \\
\hline $\begin{array}{l}\text { P1 } \\
\text { P2 } \\
\text { P3 } \\
\text { P4 } \\
\text { P5 } \\
\text { P6 } \\
\text { P7 } \\
\text { P8 } \\
\text { P9 } \\
\text { P10 } \\
\text { P11 }\end{array}$ & $\begin{array}{l}2 \\
10 \\
1 \frac{1}{1} \\
1 \frac{1}{8} \\
4 \\
2 \frac{1}{8} \\
5 \frac{1}{2} \\
8 \frac{3}{4} \\
8 \frac{8}{4} \\
3 \frac{1}{2}\end{array}$ & $\begin{array}{r}55 \\
58 \\
65 \\
66 \\
70 \\
70 \\
71 \\
83 \\
86 \\
100 \\
105\end{array}$ & $\begin{array}{l}211 \\
181 \\
161 \\
140 \\
141 \\
579 \\
190 \\
374 \\
198 \\
114 \\
178\end{array}$ & $\begin{array}{l}\text { Marasmus } \\
\text { Marasmus } \\
\text { Underweight } \\
\text { Kwashiorkor } \\
\text { Underweight } \\
\text { Pneumonia complicating bronchiectasis } \\
\text { Herpes stomatitis; meningitis } 1 \text { month ago } \\
\text { Empyema } \\
\text { Recurrent bronchopneumonia }\end{array}$ \\
\hline
\end{tabular}

Note: Arranged in ascending order of percentage expected weight.

later showed return to normal values (Cases N3, $\mathrm{N} 1$, and $\mathrm{N} 2$, respectively, in Table I).

Pneumonia (Table V). These 11 patients represented a heterogeneous group in which it may be noted that values in malnourished subjects (P1 to P7) were normal, suggesting a stimulating effect of the pneumonia episode, and continuing stimulation in the patient with bronchiectasis who had the highest response.

TABLE VI

Lymphocyte Response in Children with Miscellaneous Diseases

\begin{tabular}{l|c}
\hline \multicolumn{1}{c|}{ Diagnosis } & Lymphocyte Response \\
\hline $\begin{array}{c}\text { Chronic myeloid leukaemia (aged } 4 \frac{1}{2} \text { yr) } \\
\text { Rheumatoid arthritis (aged 10,4, and } 8 \text { yr) }\end{array}$ & $12, \star 26, \star 37$ \\
$\begin{array}{c}\text { Pulmonary tuberculosis and marasmus } \\
\text { (aged 10 yr) }\end{array}$ & 181 \\
\hline
\end{tabular}

^On prednisone treatment.

Table VI summarizes the results of a miscellaneous group of patients. Though malignancy and corticosteroids are known to suppress the immune response, we are unable to come to any conclusions regarding rheumatoid disease since 2 of 3 patients were receiving corticosteroid therapy. The patient with clinically active pulmonary tuberculosis had a normal lymphocyte response despite his being grossly malnourished.

\section{Discussion}

Lymphocyte transformation may be induced by a variety of stimuli (Ripps, Fellner, and Hirschhorn, 1965), and the degree of reactivity may be measured either morphologically or by determining the rate of
DNA synthesis by estimation of tritiated thymidine uptake (Dutton and Eady, 1964). Inability to respond to PHA stimulation by increased protein synthesis suggests an abnormality of lymphocyte function (Forbes and Henderson, 1966).

Malnutrition. The low lymphocyte transformation rates (LTR) in the kwashiorkor and marasmus patients therefore indicate impairment of lymphocyte function. Since cell-mediated immune responses are mediated by the lymphocyte (Humphrey and White, 1970; Holborow, 1970), it is reasonable to infer from our results that lowered nutritional status interferes with the hosts' cellular immune mechanisms sufficiently severely to render them susceptible to infections. A similar relation has been shown by Geefhuysen et al. (1971) and by Smythe et al. (1971), who demonstrated impaired delayed cutaneous hypersensitivity reactions to candida and diphtheria toxoid antigens, and to 2,4-dinitrochlorobenzene, respectively. In addition, the former correlated the degree of lymphocyte abnormality with the clinical severity of kwashiorkor, and the latter showed profound depletion of the thymolymphatic system.

Measles. Lymphocyte transformation was depressed more by measles than by malnutrition. The mechanism for the abnormality would seem to be that measles virus damages and/or parasitizes peripheral lymphocytes. The lymph nodes are enlarged in measles and the count of small lymphocytes is reduced in the blood (Karzan, 1968).

Our findings confirm a preliminary report by Kadowaki, Nihira, and Nakao (1970) that lymphocyte transformation by PHA was suppressed during the course of measles. These in vitro findings appear to reflect in vivo reduction of cellular 
immunity. Anergy to tuberculin is well known in measles (Starr and Berkovich, 1964), and measles lowers resistance to tuberculosis (Christensen et al., 1953).

We suggest that the reduced cellular immunity in malnutrition which we have shown in vitro reduces resistance to measles. In a malnourished child, cellular immunity and nutrition are both further impaired by measles. This vicious cycle might explain the severity of measles in underprivileged communities (Morley, 1969; Gordon, Jansen, and Ascoli, 1965).

Gastroenteritis. The finding of reduced in vitro transformation of lymphocytes from all of 12 children with gastroenteritis was not expected. These results cannot be explained by malnutrition because half the children in Table IV weighed over $75 \%$ (from $76 \%$ to $98 \%$ ) of expected weight for age when dehydrated.

Nearly all these children were outpatients with dehydrating gastroenteritis who were being treated in the special 'Drip Room' at Red Cross Children's Hospital. Blood was taken either while intravenous (IV) fluid was running or shortly after the prescribed IV 'drip' had been completed. One possibility that might explain the results is that lymphocytes may be damaged by dehydration. If so, the effect persists for some time after a rehydrating infusion has been given. There was no difference between lymphocyte responses in children still receiving IV fluids (so presumably not yet normally hydrated) and children whose drips had just been completed. It is likely that the fluid was not yet fully equilibrated in all cellular compartments. Alternatively, acidosis is usually present in gastroenteritis and is known to damage lymphocytes in vitro (Wilson and Thomson, 1968).

We have not established how long this effect of dehydrating gastroenteritis lasts. 10 to $12 \mathrm{ml}$ blood were required for each test. The effect is certainly over by a month (see Table I). Anergy to tuberculin is said to occur in severely dehydrated children (Lincoln and Sewell, 1963; High, 1969; Rich, 1944) but we are not aware of any modern study of this phenomenon or its implications.

The low lymphocyte transformations in dehydrating gastroenteritis cannot explain the low transformations in the malnourished children, since most of the latter (except K1 and K7) had only minor diarrhoea and were not dehydrated.

Pneumonia. Despite the fact that some of the children with pneumonia were severely underweight and one had kwashiorkor (Table V), the mean LTR was virtually the same as in the healthy controls. 3 of these patients are of particular interest. The highest LTR in the whole series of patients was obtained in a bronchiectatic patient who had an exacerbating pneumonia suggesting an abnormal reactivity of his lymphocytes. Contrary to expectations, the child who had herpes simplex stomatitis also had a high LTR. When herpes simplex virus infection is associated with malnutrition and/or measles, fatal dissemination is not infrequent and defective cell-mediated immunity has been incriminated (McKenzie, Hansen, and Becker, 1959; Becker, Kipps, and McKenzie, 1968; Templeton, 1970). The reactivity of this patient's lymphocytes is, therefore, of interest and it would be worth while to investigate this further in malnourished patients with associated herpes virus infection. The patient (P4) with frank kwashiorkor and pneumonia is noteworthy in that his lymphocytes were more reactive than those of any of the other children (Table II) who had PCM uncomplicated by pneumonia.

There were too few patients in the miscellaneous group for any valid conclusions to be drawn. The results (Table VI) were not unexpected since steroid therapy (Forbes and Henderson, 1966; Nelson et al., 1969), anti-inflammatory drugs (Forbes and Smith, 1967), and malignancy (Hersh and Oppenheim, 1965) are known to exert an immunosuppressant effect.

The available evidence indicates that malnutrition, measles, and gastroenteritis impair the activity of the thymus-dependent lymphocyte which is responsible for cell-mediated immune responsiveness. The mechanism of this suppression remains unclear. It may be due to an abnormality of the lymphocyte or of its environment. For instance, our study revealed no obvious association between LTR and serum albumin levels so that no clear relation could be established between protein availability and mitogenesis. It should be pointed out, however, that since amino acids are provided in the culture medium, nontransformation cannot be explained directly by protein lack, though it has been suggested that impaired cell production is one of the fundamental lesions in protein deficiency (Ramalingaswami, 1969).

The lymphocyte may be damaged by measles virus or have its metabolic functions deranged by influences such as thymic aplasia, treatment with steroids, anti-inflammatory drugs, malignancy, dehydration, acidosis, electrolyte disturbances, etc. Moreover, while adrenal function in malnutrition is not reduced (Lurie and Jackson, 1962; Alleyne 
and Young, 1966), the low serum albumin levels may conceivably contribute to an increased circulating level of the unbound cortisol fraction (Leonard and MacWilliam, 1964). On the other hand, PHA-cortisol interaction is complex (Forbes and Henderson, 1966).

It is possible that in some of the diseases we have studied the reduction of lymphocyte function resulted from plasma inhibitors (Levene et al., 1969; Gatti, 1971). Finally, since malnutrition, gastroenteritis, and treatment with corticosteroids are known to influence body electrolytes, it is possible that alterations in body potassium, an important intracellular ion, may play a role in contributing to the lymphocyte abnormality.

In view of the evidence linking in vitro lymphocyte transformation with in vivo DNA synthesis and cell-mediated immune responses, the results reported here furnish experimental support for the long-held clinical impression that malnutrition predisposes to infection (Werkman, 1923; Clausen, 1934, 1935; Cannon, 1942, 1945; Kahn et al., 1957; Scrimshaw et al., 1968; Lowenstein, 1970). Further work will need to be done to elucidate the mechanism(s) by which lymphocyte function is impaired in malnutrition.

We thank Drs. Colin Watson and Joan Parker for suggestions and advice; Mr. M. Samuels for laboratory assistance; Drs. B. E. Lewis, A. Cavvadas, and P. M. Leary for allowing us to study patients under their care; and Miss Aileen Moodie for follow-up visits.

Financial support was received from United States Public Health Service Grant AM-03995 and the South African Medical Research Council.

\section{REFERENCES}

Alleyne, G. A. O., and Young, V. H. (1966). Adrenal function in malnutrition. Lancet, 1,911 .

Becker, W. B., Kipps, A., and McKenzie, D. (1968). Disseminated herpes simplex virus infection. American fournal of Diseases of Children, 115, 1.

Brown, R. E., and Katz, M. (1965). Antigenic stimulation in undernourished children. East African Medical fournal, 42 , 221.

Cannon, P. R. (1942). Antibodies and the protein-reserves. Fournal of Immunology, 44, 107.

Cannon, P. R. (1945). The importance of proteins in resistance to infection. Fournal of the American Medical Association, 128, 360.

Christensen, P. E., Schmidt, H., Bang, H. O., Andersen, V., Jordal, B., and Jensen, O. (1953). An epidemic of measles in Southern Greenland, 1951: measles in virgin soil. III. Measles and tuberculosis. Acta Medica Scandinavica, 144, 450.

Clausen, S. W. (1934). The influence of nutrition upon resistance to infection. Physiological Review, 14, 309.

Clausen, S. W. (1935). Nutrition and infection. Fournal of the American Medical Association, 104, 793.

Cohen, S., and Hansen, J. D. L. (1962). Metabolism of albumin and $\gamma$-globulin in kwashiorkor. Clinical Science, 23, 351.

Dutton, R. W., and Eady, J. D. (1964). An in vitro system for the study of the mechanism of antigenic stimulation in the secondary response. Immunology, 7, 40.
Eijsvoogel, V. P., and Schellekens, P. T. A. (1965). The lymphocyte transformation test. (Abst.) Histocompatibility Testing 1965, p. 229. Munksgaard, Copenhagen.

Folb, P. I., and Trounce, J. R. (1971). Selective pharmacological inhibition of lymphocyte stimulation. Lancet, 2, 221.

Forbes, I. J., and Henderson, D. W. (1966). Globulin synthesis by human peripheral lymphocytes. Annals of Internal Medicine, $65,69$.

Forbes, I. J., and Smith, J. L. (1967). Effects of anti-inflammatory drugs on lymphocytes. Lancet, $2,334$.

Gatti, R. A. (1971). Serum inhibitors of lymphocyte responses. (Letter to the Editor.) Lancet, 1, 1351.

Gatti, R. A., and Good, R. A. (1970). The immunological deficiency diseases. Medical Clinics of North America, 54, 281.

Geefhuysen, J., Rosen, E. U., Katz, J., Ipp, T., and Metz, J. (1971). Impaired cellular immunity in kwashiorkor with improvement after therapy. British Medical fournal, 4, 527.

Gopalan, C., and Ramalingaswami, V. (1955). Kwashiorkor in India. Indian fournal of Medical Research, 43, 751.

Gordon, J. E., Jansen, A. A. J., and Ascoli, W. (1965). Measles in rural Guatemala. Fournal of Pediatrics, 66, 779.

Harland, P. S. E. G., and Brown, R. E. (1965). Tuberculin sensitivity following BCG vaccination in undernourished children. East African Medical Fournal, 42, 233.

Hendrickse, R. G. (1967). Interactions of nutrition and infection: experience in Nigeria. In Nutrition and Infection. Ciba Foundation Study Group, No. 31, p. 98. Ed. by G. E. W. Wolstenholme and M. O'Connor. Churchill, London.

Hersh, E. M., and Oppenheim, J. J. (1965). Impaired in vitro lymphocyte transformation in Hodgkin's disease. New England Fournal of Medicine, 273, 1006.

High, R. H. (1969). Textbook of Pediatrics, 9th ed., p. 603. Ed. by W. E. Nelson, V. C. Vaughan, and R. J. McKay. Saunders, Philadelphia.

Holborow, E. J. (1970). An A.B.C. of Modern Immunology, Chapter 6. Lancet, London.

Humphrey, J. H., and White, R. G. (1970). Immunology for Students of Medicine, 3rd ed., Chapter 12. Blackwell, Oxford.

Hutt, M. S. R. (1969). Editorial. Malnutrition and infectionEast African Studies. Fournal of Tropical Pediatrics, 15, 153.

Kadowaki, J. I., Nihira, M., and Nakao, T. (1970). Reduction of phytohemagglutinin-induced lymphocyte transformation in patients with measles. (Letter to the Editor.) Pediatrics, 45, 508.

Kahn, E., Stein, H., and Zoutendyk, A. (1957). Isohemagglutinins and immunity in malnutrition. American fournal of Clinical Nutrition, 5, 70.

Karzan, D. T. (1968). Measles. In The Biologic Basis of Pediatric Practice, p. 624. Ed. by R. E. Cooke and S. Levin. Blakiston, New York.

Keet, M. P., and Thom, H. (1969). Serum immunoglobulins in kwashiorkor. Archives of Disease in Childhood, 44, 600.

Leonard, P. J., and MacWilliam, K. M. (1964). Cortisol binding in the serum in kwashiorkor. Fournal of Endocrinology, 29, 273.

Levene, G. M. (1970). The clinical significance of lymphocyte transformation in vitro. Proceedings of the Royal Society of Medicine, 63, 349.

Levene, G. M., Turk, J. L., Wright, D. J. M., and Grimble, A. G. S. (1969). Reduced lymphocyte transformation due to a plasma factor in patients with active syphilis. Lancet, 2, 246.

Lincoln, E. M., and Sewell, E. M. (1963). Tuberculosis in Children, p. 42. McGraw-Hill, New York.

Ling, N. R. (1968). Lymphocyte Stimulation, p. 156. Wiley, New York.

Lloyd, A. V. C. (1968). Tuberculin test in children with malnutrition. British Medical fournal, 3, 529.

Lowenstein, F. W. (1970). Nutrition and infection in Africa. Nutrition Abstracts and Reviews, 40, 373.

Lurie, A. O., and Jackson, W. P. U. (1962). Adrenal function in kwashiorkor and marasmus. Clinical Science, 22, 259.

McFarlane, H., Reddy, S., Adcock, K. J., Adeshina, H., Cooke, A. R., and Akene, J. (1970). Immunity, transferrin, and survival in kwashiorkor. British Medical fournal, 4, 268.

McKenzie, D., Hansen, J. D. L., and Becker, W. (1959). Herpes simplex virus infection: dissemination in association with malnutrition. Archives of Disease in Childhood, 34, 250.

Morley, D. (1969). Severe measles in the tropics. British Medical fournal, 1, 297 and 363. 
Nelson, S. D., Mackay, J. S., Sheridan, B., and Weaver, J. A. (1969). Intermittent corticotrophin therapy study of lymphocyte transformation in vitro in rheumatoid arthritis. Annals of the Rheumatic Diseases, 28, 524.

Phillips, I., and Wharton, B. (1968). Acute bacterial infection in kwashiorkor and marasmus. British Medical fournal, 1, 407.

Ramalingaswami, V. (1969). Interface of protein nutrition and medicine in the tropics. Lancet, $2,733$.

Rich, A. R. (1944). The Pathogenesis of Tuberculosis, p. 370. Thomas, Springfield, Illinois.

Ripps, C. S., Fellner, M. J., and Hirschhorn, K. (1965). Response of lymphocytes to tetracycline. Lancet, 2,951 .

Schellekens, P. T. A., and Eijsvoogel, V. P. (1968). Lymphocyte transformation in vitro. I. Tissue culture conditions and quantitative measurements. Clinical and Experimental Immunology, 3, 571.

Scrimshaw, N. S., Taylor, C. E., and Gordon, J. E. (1968). Interactions of Nutrition and Infection (World Health Organization Monograph Series No. 57). WHO, Geneva.

Smythe, P. M., Schonland, M., Brereton-Stiles, G. G., Coovadia, H. M., Leoning, W., Mafoyane, A., Parent, M. A., and Grace, J. (1971). Thymolymphatic deficiency in protein-calorie malnutrition. In Proceedings of the XIIIth International Congress of Paediatrics, Vol. II, No. 66, p. 321 .

Starr, S., and Berkovich, S. (1964). Effects of measles, gammaglobulin-modified measles and vaccine measles on the tuberculin test. New England fournal of Medicine, 270, 386.

Templeton, A. C. (1970). Generalised herpes simplex in malnourished children. Fournal of Clinical Pathology, 23, 24.

Trowell, H. C., Davies, J. N. P., and Dean, R. F. A. (1954). Kwashiorkor, p. 62. Arnold, London.

Truswell, A. S., Hansen, J. D. L., Schendel, H. E., and Brock, J. F. (1959). Controlled trial of the protein value of maize/pea vegetable mixture for pre-school children. South African fournal of Laboratory and Clinical Medicine, 5, 63.
Vaughan, V. C., III (1969). Textbook of Pediatrics, 9th ed., p. 40. Ed. by W. E. Nelson, V. C. Vaughan, and R. J. McKay. Saunders, Philadelphia.

Venkatachalam, P. S., and Patwardhan, V. N. (1953). The role of Ascaris lumbricoides in the nutrition of the host: effect of ascariasis on digestion of protein. Transactions of the Royal Society of Tropical Medicine and Hygiene, 47, 169.

Vitale, J. J. (1971). Nutrition and infection. American fournal of Clinical Nutrition, 24, 248.

Watson, C. E., and Freesemann, C. (1970). Immunoglobulins in protein-calorie malnutrition. Archives of Disease in Childhood, 45, 282.

Watts, T. (1969). Thymus weights in malnourished children. fournal of Tropical Pediatrics, 15, 155.

Werkman, C. H. (1923). Immunologic significance of vitamins. III. Influence of the lack of vitamins on the leukocytes and on phagocytosis. Fournal of Infectious Diseases, 32, 263.

Williams, C. D. (1953). Kwashiorkor. Fournal of the American Medical Association, 153, 1280.

Wilson, D., Bressani, R., and Scrimshaw, N. S. (1961). Infection and nutritional status. I. The effect of chicken-pox on nitrogen metabolism in children. American fournal of Clinical Nutrition, 9, 154.

Wilson, J. D., and Thomson, A. E. R. (1968). Death and division of lymphocytes: neglected factors in assessment of PHAinduced transformation. Lancet, 2, 1120.

Correspondence to Dr. E. Bhettay, Department of Paediatrics and Child Health, University of Cape Town Medical School, Observatory, Cape Town, South Africa. 